TEME, г. XLIII, бр. 2, април - јун 2019, стр. 599-615

Прегледни рад $\quad$ https://doi.org/10.22190/TEME171220036B

Примљено: 20. 12. 2017.

UDK 316.32:323(497.11)

Ревидирана верзија: 15. 4. 2019.

Одобрено за штампу: 17. 4. 2019.

\title{
ПОИМАЊЕ СУВЕРЕНОСТИ И ГЛОБАЛИЗАЦИЈЕ СА АКЦЕНТОМ НА СРПСКИ ТРАНЗИЦИОНИ ДИСКУРС
}

\section{Војислав Бачанин}

\author{
Универзитет у Крагујевцу, Правни факултет, Крагујевац, Србија \\ bacaninvojislav@gmail.com
}

\begin{abstract}
Апстракт
Иако је процес преласка са централнопланске на тржишну привреду у Србији започет почетком 90-их година прошлог века, домаћи транзициони дискурс нарочито постаје актуелан тек након петооктобарских промена 2000. године. Започете структурне промене утицале су на све раширенију научноистраживачку дебату о глобализацијским и транзиционим процесима, која и даље не губи на актуелности. За разлику од знатно заступљених афирмативних осврта на глобализационе процесе у првој деценији 21. века, другу деценију су у погледу ових расправа више карактерисале критички настројене дебате о последицама глобализације. У оквиру њих, као „верни пратилац” појма глобализације, неретко се користи појам суверености, нарочито у оном „постисторијском” контексту слабљења државе као институције. С обзиром на то да су ове дебате и даље у значајном обиму заступљене на домаћим друштвено-хуманистичким научноистраживачким платформама, чини се да би мултидисциплинарно третирање ових појмова могло додатно да осветли њихову природу и укаже на могуће недоследности и њихову неадекватну употребу. У средишту анализе је, стога, проблем односа појмова суверености и глобализације, који се сагледава како кроз осврт на различита поимања у теоријскоправној, уставноправној и међународноправној доктрини тако и кроз осврт на већ неко време актуелне тенденције у домаћим социолошким, економско-политичким и политиколошким дебатама.
\end{abstract}

Кључне речи: глобализација, транзиција, сувереност, држава, „држава благостања”.

\section{UNDERSTANDING OF SOVEREIGNTY AND GLOBALIZATION WITH EMPHASIS ON SERBIAN TRANSITIONAL DISCOURSE}

\begin{abstract}
Even though the process of transition from a centrally planned to a market economy in Serbia started in the early 90's of the last century - domestic transitional discourse becomes increasingly predominant only after the changes that occurred on
\end{abstract}


the 5th of October 2000. Structural changes that were initiated have influenced an increasingly widespread scientific and research debate on globalization and transitional processes, which remains relevant to this date. In contrast to the prevalent affirmative views on globalization processes in the first decade of the 21st century, the second decade was, in terms of these discussions, characterized more by critically-minded debates on the consequences of globalization. Within these debates as a "loyal companion" of the notion of globalization, the notion of sovereignty is often used, especially in that "post-historical" context of the weakening of the state as an institution. Given that these debates continue to be considerably present within domestic social sciences and humanities research platforms, it seems that the multidisciplinary approach to these concepts could shed additional light on their nature and point out to the possible inconsistencies and inadequate use. Therefore, in the focus of the analysis is the problem of the relation between the concepts of sovereignty and globalization, which is observed both with reference to different concepts in the theoretical, constitutional and international legal doctrine, and to the already existing tendencies in domestic sociological, economic and political debates.

Key words: $\quad$ globalization, transition economy, sovereignty, state, welfare state.

\section{УВОДНА РАЗМАТРАЬА}

Уназад скоро три деценије, појмови глобализације и суверености предмет су незаобилазне дебате у домаћој јавној сфери. Штавише, када би се спровело какво опсежније истраживање анализе садржаја најзаступљенијих појмова, како на масмедијском тако и на научном нивоу, заинтересованог читаоца свакако не би зачудила чињеница да се ова два појма, уз незаобилазни појам „транзиције”, већ дуго налазе при самом врху неког квантитативног табеларног приказа.

Пошто је глобализација друштвени феномен са широким импликацијама, њено сагледавање нужно изискује не само економску већ и ширу анализу. Са друге стране, институт суверености чини се и даље претежно правним и политичким појмом, те се, стога, чини пожељним и његово интегрално ${ }^{1}$ сагледавање.

У оквиру дебата о проблемима глобализације као њен „верни пратилац" неретко се користи појам суверености, нарочито у оном „Постисторијском” контексту слабљења државе као институције. С обзиром на то да су ове дебате и даље у значајном обиму заступљене на домаћим друштвено-хуманистичким научноистраживачким платформама, мултидисциплинарно третирање ових појмова могло би, макар и у овом скромном облику, додатно да осветли њихову природу и укаже на могуће недоследности и њихову неадекватну употребу.

\footnotetext{
${ }^{1}$ Интегрално проучавање права подразумева тежњу великог броја савремених аутора да се при истраживању правних института осветли не само нормативна већ и њихова економска, социјална и вредносна димензија. „Према интегралним концепцијама права, право је посебан друштвени процес где су понашања, вредносни ставови и нормативна свест до те мере узрочно, функционално и смислено међузависни да ниједан од тих састојака не може бити сазнат ако се издвоји од других" (Трајковић, 2009, стр. 105).
} 
Сходно томе, настојаће се сагледати проблем односа појмова суверености и глобализације, како кроз осврт на различита поимања у теоријскоправној, уставноправној и међународноправној доктрини тако и кроз осврт на већ неко време актуелне тенденције у домаћим социолошким, економско-политичким и политиколошким дебатама. Циљ је, дакле, да се коришћењем теоријске анализе, компаративног и историјског метода означе највидљивији аналитички проблеми и бар унеколико пружи могућност ширег, али и ефектнијег сагледавања ових сложених појмова.

\title{
ТЕОРИЈСКОПРАВНИ И ПОЛИТИКОЛОШКИ ОКВИР СУВЕРЕНОСТИ
}

Кад је крајем 19. века Слободан Јовановић постао професор државног права београдске Високе школе, у свом приступном предавању покушао је будуће правнике упозорити на широк дијапазон теоријских ставова о појму суверености:

\begin{abstract}
„Ниједно питање у науци о држави не може бити у тој мери спорно као питање о суверености, питање о природи државне власти, о њеним границама, о њеној основи. Оно је спорно управо толико, да би се могло мислити да му је суђено остати увек отворено. Треба ли додати да му главна привлачност баш отуда долази? Баш зато што је то питање важило за нерешиво, најбољи умови покушавали су да му пронађу решења, и то нису били увек само правници, него такође философи, моралисти, чак и прости књижевници. Резултати до којих су они дошли не морају увек бити тачни, али не могу да не буду занимљиви” (Јовановић, 1996, стр. 5).
\end{abstract}

Још од античког доба, питања постанка, извора и домета власти заокупљала су пажњу многобројних мислилаца. Ипак, иако су теоријски домети старогрчких и римских мислилаца, као и представника средњовековне патристике и схоластике умногоме допринели настанку и развоју елементарних правних института, и како је, у том периоду цивилизацијског развоја, било веома тешко одвојити природно од позитивног права - прво појмовно и терминолошко одређење суверености традиционално се везује тек за 16. век и чувено дело „Шест књига о републици” Жана Бодена (Jean Bodin). ${ }^{2}$

\footnotetext{
${ }^{2}$ Термин „сувереност” потиче од старофранцуског sovrain. Посматрајући етимологију овог термина, који је изворно одређивао неку особу са вишим друштвеним положајем, Крбек је (Ivo Krbek) указивао на интересантну „ренесансу” појма суверености: „Док је раније тај израз значио само компаратив, неки виши степен власти, у 16. веку се тај компаратив дефинитивно претвара у суперлатив
} 
Боден се, такође, неретко сматра утемељивачем прве модерне теорије о суверености - теорије монархијске суверености. Заговорници овог теоријског правца сматрали су, наиме, да сва власт припада и мора припасти монарху, а то су оправдавали било кроз позивање на природноправне законе и божја откровења, било кроз сагледавање монархове владавине као својеврсног заштитног фактора. ${ }^{3}$ Боденова позната дефиниција - да је суверена она власт која споља не зависи ни од које друге власти, а изнутра мора бити виша од било које друге - ни данас не губи на својој актуелности и неизоставна је као уводник у већини савремених уџбеничких анализа овог појма. У оваквим анализама, многи аутори ужег теоријскоправног усмерења као други камен темељац овог концепта често узимају дело Томаса Хобса (Thomas Hobbes). Хобс „прихвата Боденово одређење да је сувереност обележје државе, али додаје да је сувереност и суштина државе" (Симић, Ђорђевић, Матић, 2009, стр. 89). За разлику од Боденовог становишта да се монарх може у свом делању ограничити само нормама „божанског права”, Хобс ову теоријску нит у свом „Левијатану" умногоме и секуларизује, пружајући јој, тако, овоземаљску ноту, ${ }^{4}$ те га, између осталог и стога, поједини аутори сматрају родоначелником правног позитивизма (Tadić, 1996, str. 194).

Друштвене промене на европском континенту током 17. и 18. века условиле су и теоријско скретање водећих правних мислилаца тог времена у погледу субјекта коначне и последње речи у држави. Ово скретање најбоље илуструју схватања Џона Лока (John Locke) и Жан-Жака Pусоа (Jean-Jacques Rousseau), који се сматрају творцима теорије народне суверености. ${ }^{5}$ Носилац суверености више није монарх, већ - народ. ${ }^{6}$ Сувереност се, тако, почиње посматрати као на-

и суверенитет је значајка власти која над собом нема више власти, нити зависи од неке друге власти" (Krbek, 1964, str. 50).

${ }^{3}$ У том смислу, још је Гроцијус (Hugo Grotius) писао: „По римском и хебрејском праву сваком је дозвољено да се прода као роб ако му се то свиђа. Зашто не би било дозвољено неком народу који припада самом себи да се подвргне једном човеку или неколицини, да пренесе право владања над собом, па да чак не задржи ни један део тог права... Има више разлога због којих се народ може одрећи своје суверености: кад се сматра угроженим или кад теран глађу не види друго средство да нађе свој спас" (Mratović, Filipović, Sokol, 1986, str. 214).

4 „Сама тврдња о директном уговору с Богом толико је очигледна лаж, чак и у свести самих оних који је постављају, да није само чин неправедног, већ подлог и нечовечног настројења" (Hobs, 2004, str. 124).

5 „И теорија народног суверенитета, особито у свом почетку, често конфундира државни суверенитет с народним суверенитетом: она просто замјењује монарха с народом и срж јој је суверенитета врховна државна власт" (Krbek, 1965, str. 8).

${ }^{6}$ Дакако, то не значи да је концепт монархијске суверености постао историјски превазиђен и изгубио своје заговорнике, већ је само претрпео различите модификације. Хегел је (Georg Wilhelm Friedrich Hegel), на пример, сматрао да се 
родна - недељива и неотуђива, ${ }^{7}$ а ње се народ не може одрећи, нити њено вршење пренети на друге. ${ }^{8}$ Како је истицао Русо, у држави постоји „заједничка снага која је одржава и општа воља која управља том снагом, а примена једне на другу чини сувереност” (Rousseau, 1993, str. 63).

Представници концепта националне суверености, међу којима су најпознатији француски аутори Есмен (Adhémar Esmein) и Малберг (Raymond Carré de Malberg), за носиоца суверености узимају нацију. Нација, као појам, разуме се у контексту континуитета прошлих, садашњих и будућих генерација. Према Малберговом схватању, сувереност се „не налази код појединаца ub singuli, већ у идеалној универзалности (колективном бићу) нације, независном и одвојеном од појединаца" (Grubić, 2014, str. 20).

Крајем 19. и почетком 20. века, у немачкој правној мисли, афирмишу се две познате теорије суверености - (тзв. класични) концепт суверености државе и концепт суверености права. Аутори који се сматрају творцима класичне теорије државне суверености Лабанд (Paul Laband) и Јелинек (Georg Jellinek) - заступали су став да „сувереност није јавна власт, већ само извесно својство јавне власти" (Диги, 1929, стр. 25). Такође, сматрали су да суверену власт не би требало посматрати као свемоћ државе, већ као својеврсно самоограничење државне власти.

\begin{abstract}
„Држава саму себе ограничава када повлачи границу између себе и личности индивидуе и када признаје да је индивидуална област принципијелно изузета из ауторитета државе. Тако се сувереност државе показује као сувереност над слободним људима или лицима. Јелинек је био уверен да је овом правном конструкцијом истовремено спасао и суверенитет државе и слободу лица.” (Tadić, 1996, str. 235-236)
\end{abstract}

С друге стране, заступници концепта суверености права акценат су стављали на питање правног поретка. Крабе је (Hugo Krabbe), тако, правио разлику између државне суверености, која се везује за личну власт, тј. власт људи, и правне суверености, као безличне власти права (Krbek, 1964, 101-102). Келзен (Hans Kelsen) већ, будући

народна сувереност „не може супротставити монарховој, јер народ без монарха представља неорганизовану масу. Монарх као врх државе нужан је, па зато у државама које нису монархије увек искрсава неки шеф који врши ту улогу" (Лукић, 2014, стр. 23).

7 Лок је, на пример, сматрао да „народ задржава увек право да се брани против сваке власти, па и саме законодавне власти, која се врши против њега, а не у његову корист" (Krbek, 1965, str. 57).

${ }^{8}$ Сходно познатом Русоовом схватању да је сувереност изражавање опште воље (volonté générale) народа и да се може пренети само власт, а не и воља. 
да није правио разлику између државе и правног поретка, одређивао се према појму суверености као према искључиво појавном облику уоквиреном правним системом ${ }^{9}$ и наглашавао:

„Државе које у поређењу са такозваним великим силама уопште немају реалну моћ која долази у обзир важе као суверене исто као и те велике силе. Питање да ли је држава суверена јесте питање да ли се државни правни поредак претпоставља као врховни" (Kelzen, 2000, str. 256).

На крају, може се закључити да доктрина уже теоријскоправне и уставноправне области обилује великим бројем суштински различитих теорија суверености. Такође, знатан је број и оних аутора који су заклети противници идеје суверености и који, попут Дигија (Léon Duguit), посматрају све ове анализе суверености као „доконо расправљање" (Krbek, 1964, str. 104), ${ }^{10}$ саму сувереност као мит ${ }^{11}$, а државу - као „апстракцију” (Марковић, 1927, стр. 24). Уважавајући све ауторске напоре и већину аргумената, да̂ се приметити да је Јелинек био у праву када је говорио да „за многе писце државно право није предмет сазнања, него је предмет схватања" (Јелинек, 1998, стр. 99).

Према старој српској конституционалној традицији, појам суверености посматрао се двојако - очима унутрашњег, као и међународног јавног права. Милован Миловановић је, тако, писао:

„Са гледишта међународног права, које сматра државу као члана међународне заједнице и одређује њен положај према другим државама, суверенитет није ништа друго до право сваке државе да се организује у својој унутрашњости, како за добро нађе, и да по својој вољи регулише правне односе са другим државама, не вређајући при томе њихова суверена права" (Миловановић, 1997, стр. 117).

Слично становиште могло би се приписати и савременом конституционалисти Ратку Марковићу. Он прихвата Лукићево (Радомир Лукић) одређење суверености као појма који се може рашчланити на три елемента: спољни, унутрашњи и синтетички. Према Марковићу,

\footnotetext{
${ }^{9}$ Слободан Јовановић је, такође, сувереност поимао као „чисто формалан појам” позивајући се, притом, на познату Јелинекову теорију (Јовановић, 1922, стр. 130).

${ }^{10}$ Међу заговорницима теорије о негирању суверенитета, која се садржински враћа дискурсу школе природног права, у домаћој литератури нарочито се истиче Рајко Кузмановић. Он, тако, истиче да „се морамо ослободити појма и садржаја суверенитета, као оптерећења и заблуде о његовој свемогућности, идеалу и заштитнику" (Кузмановић, 1999, стр. 219).

${ }^{11}$ Аргументујући своју тезу о народној суверености као својеврсном миту, Диги додаје: „Фатално, раније или доцније, стваралачка подлост мита се исцрпљује и стварност поново загосподари” (Диги, 1929, стр. 16).
} 
спољни елемент подразумева да је државна власт „правно слободна од сваког спољашњег мешања" (Марковић, 1995, стр. 179).

Сувереност заслужује централно место у оквиру разматрања основних права државе као субјекта међународног права. ${ }^{12}$ За разлику од ужих теоријскоправних и уставноправних концепција, у оквиру теорија из уже области међународног јавног права присутна су много једноставнија сагледавања проблема суверености, која се, дакако, не састоје од чисто семантичких аргумената. У групу раних академских демистификатора свакако би се могао уврстити и Ле Фир (Louis Le Fur), чији је познати уџбеник Међународног јавног права један од првих преведених уџбеника на српски језик у прошловековном међуратном раздобљу. Осим што наглашава да постоји само једна - недељива сувереност, ${ }^{13}$ за коју је друго име независност, Ле Фир, такође, наводи:

\begin{abstract}
„Мора увек да постоји власт која ће последња да решава и чије се одлуке не могу изменити или наново испитивати; ова највиша власт (suprema, superana) зове се сувереност, и управљачи могу њу у ствари погрешно да примењују јер и они греше, као и сви остали људи" (Ле Фир, 1934, стр. 71).
\end{abstract}

Водеће модерне концепције суверености у оквиру теорија међународног јавног права могле би се поделити у две велике групе на традиционална, апсолутна схватања суверености ${ }^{14}$ и на тзв. теорије самоограничавајуће суверености. Теза о неограниченом, апсолутном суверенитету „који је на међународном плану значио неограничену слободу акције и право интервенције у послове других земаља" (Аврамов, Крећа, 2007, стр. 97) сматра се неодрживом у светлу савременог међународног права. С друге стране, сва „самоограничавајућа" схватања суверености представљају својеврсне покушаје помирења постојања платформе међународног права и постојања суверених држава. Она би се условно могла посматрати као конвенционална поимања. Сматра се, наиме, да је држава слободна да делује својевољно у домену своје унутрашње надлежности, али је правно везана у погледу придржавања међународноправних обавеза.

\footnotetext{
${ }^{12}$ Још је Милета Новаковић, давне 1936. године, сувереност дефинисао као „несумњиву основу свих ових права” (Новаковић, 1936, стр. 61), а слично мишљење је изнео касније и Владимир Иблер (Vladimir Ibler) у свом чувеном „Речнику међународног јавног права” (Ibler, 1972, str. 290).

${ }_{13}$ У домаћој литератури, недељивост појма суверености међу првима је концепцијски прихватио Милан Бартош, истичући да би подела „унутрашње” и „спољашње” независности „била немогућа” (Bartoš, 1954, str. 272).

${ }^{14}$ Ове тезе апсолутне суверености Сенад Ганић назива „неовествалтизмом” (Ганић, 2012, стр. 28-40). Начелно посматрано, чини се да је ово више него успело терминолошко одређење.
} 
Нешто другачије виђење овог (само)ограничавања имају аутори који прихватају теорију условног суверенитета (conditional sovereignty). Они сувереност посматрају кроз призму међународних људских права и одређују је - не као право, већ као обавезу и одговорност. Оваква поимања суверености нарочито постају заступљена након пада Берлинског зида и могу се посматрати као доктрине путем којих се оправдавају тзв. хуманитарне интервенције. Тај „нови суверенитет” могли бисмо дефинисати као „способност државе да партиципира у интернационалним и супранационалним режимима, мрежама и институцијама које све више постају део међународних интеракција" (Kelleh, 2012, p. 20).

Међу бројним политиколошким анализама учестало је и распарчавање појма суверености на неколико различитих значења. Једна од познатијих класификација суверености тог типа је и подела коју је изнео Краснер (Stephen D. Krasner). Он одређује четири различита значења суверенитета: суверенитет међусобне зависности (способност држава да контролишу кретање људи и роба у оквиру својих граница), домаћи суверенитет (уставноправна форма суверенитета), вествалски или вателијански суверенитет (монопол државе у одлучивању који искључује утицаје неке спољашње власти) и међународноправни суверенитет (способност државе на међусобно признање и самоограничење кроз улазак у добровољне уговорне односе). Како се ова значења не могу повезати у једну целину, при коришћењу овакве методологије могуће је да у случају појединих држава нису задовољени сви ови услови. Могуће је, тако, да држава има задовољено вествалско значење суверенитета, али да није задовољен услов суверенитета међусобне зависности (пример Сомалије деведесетих година прошлог века) (Krasner, 2001, p. 231-233).

\section{ФЕНОМЕН ГЛОБАЛИЗАЦИЈЕ}

Иако је феномен глобализације од краја осамдесетих година 20. века један од најупотребљаванијих појмова у друштвеним и хуманистичким наукама, и даље се чини веома незахвалним задатком пружити неку општеприхваћену дефиницију „глобалног села”. Овај омнипотентан термин у свакодневном говору користи се за све - „од интернета до хамбургера" (Clark, 1999, p.35), а, парадоксално, мало шта конкретно и једноставно објашњава. С друге стране, на терену научних дебата, оружје је које се користи у расправама сукобљених аутора многих научних дисциплина, како на идеолошком тако и на чисто теоријском нивоу. Штавише, и са̂м процес глобализације онемогућује ауторе да дођу до неког поједностављеног и општеприхваћеног поимања стварности, на шта је скретао пажњу Бодријар (Jean Baudrillard) и пре почетка „краја историје” (Bodrijar, 1991, str. 95). 
С тим у вези, могло би се закључити да глобализацију није дефинисао само онај који није писао о њој. Једни у њој виде „крај историје", други - обичан мит. Поједини виде американизацију света, други - само стварање хомогеног света. Неки се задовољавају само њеним економским ефектом, а други акценат стављају на њен културолошки домет. ${ }^{15}$ Сигурно је једино то да је и даље актуелно оно на шта је давно указивао Семјуелсон (Paul Anthony Samuelson) „ми тако живимо у свету са којим ниједан пророк није рачунао” (Samuelson, 1969. str. 767).

Према Кастелсу (Manuel Castells Oliván), једном од првих гласноговорника идеје о глобализацији света и творцу тезе о тзв. умреженом друштву, друштвени поредак данашњице делује „као аутоматизовани, случајни след догађаја, изведених из необуздане логике тржишта, технологије, геополитичког поретка или биолошке одређености" (Castells, 2000, str. 500).

Међу економистима је општеприхваћено становиште да је глобализација заправо други назив за ширење модерног облика капитализма по свету, са доминантном улогом неолибералне и либертаријанске политичке филозофије. Положај државе у контексту економске глобализације није нимало захвалан - транснационалне компаније стекле су могућност да извозе своје послове у оне делове света где је цена радне снаге најнижа и где могу пронаћи најповољније фискалне услове и најпогоднију инфраструктуру. Ако се ти услови покажу неповољним, тј. исувише скупим за инвеститоре, неинвестирање у те државе постаје својеврсно економско кажњавање ових земаља.

Сама неолиберална парадигма, у литератури често неодвојива од економског поимања глобализације, традиционално се везује за тзв. Вашингтонски консензус из 1989. године. Овај акт садржао је десет тачака путем којих су биле дефинисане неопходне структурне реформе задужених земаља како би се смањио утицај тих држава у националној привреди, а привукао страни капитал. Очекивало се да ће тако због либерализације глобалних међународних и финансијских токова светски доходак бити равномерније распоређен. Ипак, Вашингтонски консензус, како је искуство не само макроекономских

\footnotetext{
${ }^{15}$ Социолози су, углавном, сагласни да би се различита поимања могла разврстати у три школе мишљења, према познатој класификацији Дејвида Хелда (David Held): 1. Скептици, аутори који сматрају да се савремено стање разликује од прошлости само по интензитету међународних интеракција; 2. Хиперглобалисти, мешовита група аутора - од оних који прихватају „крај историје”, оних који сматрају да су силе тржишта моћније од влада до оних који сматрају да је глобализација завршена и да је сад „постглобализовано” доба; 3. Трансформационалисти - аутори који сматрају да државе не губе суверенитет, већ се у њима врши својеврсно реструктурирање.
} 
шокова показало, у великој мери није остварио жељене позитивне ефекте. Уз познате преврате против конкретних политика либерализације у економски мање развијеним државама, готово сваки састанак Светске банке, Светске трговинске организације, Међународног монетарног фонда или групе Г20, уназад већ скоро две деценије, прате масовни протести, који понекад попримају и размере правих уличних ратова. ${ }^{16} \mathrm{C}$ друге стране, знатан је број и академских критичара стања глобалне економије и растући број оних који се као већ осведочени заговорници неолибералне парадигме трансформишу у неокејнзијанце. Овакав исход и не чуди јер је, упркос глобално заступљеној TINA ${ }^{17}$ агенди и „математици”, која је јамчила просперитет и смањење сиромаштва, фактички све очигледнија растућа подела на богате, који су још богатији, и сиромашне, који су још сиромашнији. Највећи парадокс је у томе што се цео тај процес дешава истовремено са просечним годишњим растом светског дохотка од око 2 до $3 \%$.

На Балкану, глобализацијски токови условили су, дакако, и мноштво позитивних ефеката, нарочито на плану демократизације политичких система. Међутим, како је истакао Крастев (Иван Кръстев), у балканским транзиционим политичким оквирима гласачи су слободни да мењају владе, али су врло ограничени кад је у питању промена политике, „избор Владе је плод љубави са бирачким телом, али је она у браку са међународним донаторима" (Krastev, 2002, p. 29). Видљиви резултати реформаторске политике су слабљење индустријске производње, хронични буџетски и спољнотрговински дефицити са истовременим растом јавног дуга. Многобројна домаћа предузећа су се због уласка ефикаснијих страних конкурената затворила и тако условила специфичну „креативну деструкцију” у виду огромног броја незапослених лица, док је нестабилност токова робе, услуга и капитала изазивала макроекономске нестабилности и/или шокове.

На глобалном нивоу, након 2008. године, осећала се потреба за променама са циљем оптималне регулације свих ефеката које је условило тзв. саморегулишуће тржиште. Један од оваквих начелних програмских докумената је и тзв. Сеулски консензус, усвојен 2010. године на нивоу групе Г20, који препоручује већу сарадњу међу државама и начелно омогућује неке форме активнијег државног утицаја, отклањајући тако многе слабости Вашингтонског консензуса. Свакако, тешко је дати прогнозе даљег глобалног економског развоја. Вероватно се решење, као и за многа друга друштвено значајна питања, налази на

\footnotetext{
${ }^{16}$ Мноштво је примера оваквих антиглобалистичких демонстрација - од Сијетла 1999. године, Ђенове 2001. године, па све до протеста у Хамбургу 2017. године, са крилатицом „добро дошли у пакао”.

${ }^{17}$ TINA је акроним за There is no alternative (не постоји алтернатива, прим. прев.).
} 
размеђи два екстремна става, у овом случају - неокејнзијанског и неолибералног. У том смислу, чини се да Пикети (Thomas Piketty) правилно апострофира да би ваљало створити инструментаријум за контролу „над финансијским капитализмом који дивља и стално обнављати и модернизовати порески систем и систем социјалних трансфера" (Piketi, 2014, str. 508).

\section{ПОИМАЊЕ СУВЕРЕНОСТИ У ГЛОБАЛИЗАЦИЈСКОМ КОНТЕКСТУ У ДОМАЋИМ ДРУШТВЕНО-ХУМАНИСТИЧКИМ ДЕБАТАМА}

На домаћем научноистраживачком простору дебате о суверености држава у глобализацијском контексту заступљеније су у оквиру политиколошких, социолошких и филозофских расправа него у оквиру правних анализа. ${ }^{18}$ Приметно је, такође, да знатан број закључака објављених радова и излагања на скуповима и конференцијама карактеришу врло сродни, а покаткад и подударни ставови. Значајан број осврта, сада већ традиционално, акцентује губитак или слабљење политичке моћи државних структура у односу према регионалним, међународним или транснационалним ентитетима, док се у закључним ставовима учестало инсистира на поимањима која су својствена тзв. средњем путу, тј. трансформисаној улози и даље суверене државе у глобалним оквирима.

Славиша Орловић истиче да је сувереност „данас подељена између националних, интернационалних и понекад, регионалних власти". На губитак или смањење суверенитета, према Орловићу, утичу „глобална економија, нове форме глобалног управљања, међународни војни савези и међународно право" (Orlović, 2010, str. 263).

Брацо Ковачевић у својој монографији „Држава и десуверенизација" прецизира:

„На процесе угрожавања суверености као процесе десуверенизације утиче читав низ фактора и организација. Међу најутицајнијима свакако треба поменути Организацију Уједиње-

\footnotetext{
18 Уз многобројне прегледне и изворне научне чланке у домаћим часописима са овом тематиком, ова тема била је и предмет неколико конференција - попут Међународне научне конференције „Глобализација и десуверенизација”, одржане од 14. до 15. септембра 2013. године на Филозофском факултету Универзитета у Приштини са привременим седиштем у Косовској Митровици, као и Међународне научне конференције „Глобализација и сувереност - са освртом на Босну и Херцеговину”, одржане од 25. до 26. септембра 2014. године у Бањој Луци, коју су организовали Факултет политичких наука у Бањој Луци и Европски дефендологија центар за научна, политичка, економска, социјална, безбједносна, социолошка и криминолошка истраживања из Бање Луке.
} 
них нација (sic), моћне државе, НАТО-пакт, Европску унију, Свјетску банку, Међународни монетарни фонд, Свјетску трговинску организацију, мултинационалне корпорације итд. Заправо, оне настоје да створе оно што се у колоквијалном смислу назива новим свјетским поретком” (Kovačević, 2016, str. 55).

Миле Ракић пак десуверенизацију одређује као „евроатлантски транснационални корпорацијски империјализам” и закључује:

„Данас на почетку 21. века дошло је друго време, време глобализације и глобализма, време кад финансијске олигархије и транснационалне компаније не бирају средства и све су агресивније у њиховим плановима да остваре своје економске интересе, разарајући националне државе споља и изнутра, вршећи њихову десуверенизацију” (Rakić, 2014, str. 407).

У неким анализама чини се као да се превиђају поједине конвенционалне норме међународноправног карактера и вишедеценијска улога држава у међународноправном саобраћају. Тако, Ирина Ковачевић наглашава: „Нема ниједног више питања које је ексклузивно право националне државе, већ је свако питање трансдржавног, наддржавног, извандржавног, глобалног карактера" (Kovačević, 2013, str. 442), Радомир Нешковић истиче да је сувереност одређена „укупном снагом државе у економском, географском, људском и војном смислу и њеним капацитетом да утиче на међународне односе" (Nešković, 2014, str. 75), док Матеј Савић закључује да је „ерозија државног суверенитета почела са првим модерним међудржавним уговором међународног јавног права" (Савић, 2014, стр. 361).

Поједини аутори пружају чак и знатно шире дефиниције суверености и десуверенизације. Лазо Ристић, на пример, сматра да се „десуверенизација (...) може одвијати у свим друштвеним сферама (а да је) посебно (...) појачано инсистирање на такозваним (sic) међународним нормама које се тичу људских права" (Ristić, 2014, str. 13). Према Зорану Видојевићу, категорија суверености још је шира:

„Она је егзистенцијална, политичка, економска и духовна категорија, колективна и лична. Без личног суверенитета у коме слобода и достојанство имају централни значај за појединца и обележја су моралног става већине грађана, што подразумева цивилизацијску, као и системску, али и карактерно-вредносну подлогу - не може бити ни стварног државног суверенитета" (Видојевић, 2013, стр. 195).

Дакако, међу различитим анализама се налази и одређени број радова чији аутори нарочито истичу економску страну суверенитета. Једну од аргументованијих дефиниција економске аутономије држава пружа Фикрет Чаушевић (Fikret Čaušević): 


\begin{abstract}
„Основна обиљежја аутономности и суверености држава у економском смислу подразумијевају сљедећа три минимална услова: постојање централне монетарне институције која има дискрециону моћ измјена количине новца у оптицају и утицаја на формирање краткорочних каматних стопа; могућност емисије јавног дуга уз флексибилност вођења политике јавних расхода у складу са смјером пословног циклуса (пад пословног циклуса би требао бити подржан растом буџетских расхода и обратно), и могућност утицаја на девизни курс којим је могуће стимулисати или дестимулисати размјену роба и услуга са иностранством, као и токове капитала (приливе и одливе)" (Čaušević, 2004, str. 88).
\end{abstract}

Владимир Вулетић, такође, сматра да се посебна пажња ваља пружити економском дискурсу. Он, чини се, правилно закључује да кључна промена под утицајем глобализације није толико „везана за поткопавање суверенитета колико за поткопавање државе благостања - једног специфичног облика државе који је развијен током XX века" (Вулетић, 2013, стр. 263).

\title{
УМЕСТО ЗАКЉУЧКА
}

Иако је процес преласка са централнопланске на тржишну привреду у Србији започет почетком 90-их година прошлог века, домаћи транзициони дискурс нарочито постаје актуелан тек након петооктобарских промена 2000. године. Започете структуралне промене утицале су на све раширенију научноистраживачку дебату о глобализацијским и транзиционим процесима, која и даље не губи на актуелности. За разлику од знатно заступљених афирмативних осврта на глобализационе процесе у првој деценији 21. века, другу деценију су у погледу ових расправа више карактерисале критички настројене дебате о последицама глобализације. Једна од тема која се наметала и постала неизоставно присутна у оквиру оваквих дебата јесте и питање суверености држава у глобализованом свету.

Сведоци смо да је процес глобализације довео до слабљења политичке и економске моћи држава у односу према регионалним, међународним и транснационалним ентитетима. Логика капитала, којој је увек циљ избегавање политичке и правне регулације, и логика политике, којој је увек циљ контролисање ове прве - представљају основу међународних односа вековима уназад. Нису ретке појаве да држава жртвује свој економски просперитет како би очувала политичку независност, као своју врховну вредност. Такође, сваки однос мора имати свој аспект моћи. Међутим, изучавање тог аспекта предмет је изучавања политике. Правни оквир је само ту да пружи платформу која ће обезбедити да се уз сталне флуктуације на крају омогући равнотежа моћи. 
Уважавајући ауторски напор свих оних писаца у широкој области друштвених наука који су се определили за дистинкцију тзв. унутрашње и спољашње суверености, распарчавање појма суверености, прихватање или пак његову негацију у форми тзв. десуверенизације, чини се да се појам суверености у формалноправном смислу није променио. О ерозији суверености, десуверенизацији или сличним схватањима могли бисмо говорити само као о питању разумевања политичког односа моћи. Улога држава заиста се на политичком и економском нивоу трансформисала од краја Другог светског рата, али сувереност, као неопходни сегмент једне од елементарних норми међународног јавног права и даље не губи на својој снази. Државе и надаље остају доминантни ентитети у међународним односима. Оне управљају и надзиру међународне организације, имају огромну војну моћ и пресудан утицај на деловање војних савеза и, не мање значајно, врше веома битне друштвено-економске функције. Чини се да се, макар у овом тренутку и на овом пољу, не може пронаћи какав други ентитет као жесток конкурент државама. Политичка функционалност држава зависила је и зависиће претежно од кооперативних способности њиховог деловања. Буду ли у средишту светске јавне сфере и даље питања попут мигрантских криза, еколошких проблема и оружаних сукоба, повећаваће се моћ међународних организација. А њих без држава - нема.

На крају, економска међузависност остаје на линији основе међународних односа. Не може се пренебрегнути чињеница да је утицај ММФ-а, Светске банке или СТО на нивоу макроекономске стабилности већине држава и даље доминантан. Ипак, чини се да тај утицај није толико везан за ерозију суверенитета или некакву десуверенизацију држава као субјеката међународног права колико је везан за ерозију државе благостања, као ширег друштвеног конструкта. Сходно томе, како би се избегле недоумице у сагледавању сложеног појма суверености, препоручљиво би било да се у будућим научноистраживачким подухватима, којих ће свакако бити, аутори превасходно определе за одређени методолошки приступ, а након тога одлуче за конкретни концепт суверености, као и његову правну, економску или политичку контекстуализацију и тек онда пруже какву вредносну оцену.

\section{ЛИТЕРАТУРА}

Аврамов, С., Крећа, М. (2008). Међународно јавно право: двадесето издање [Public International Law: 20th edition]. Београд: Савремена администрација.

Bartoš, M. (1954). Međunarodno javno pravo: I knjiga [Public International Law: Book I]. Beograd: Kultura.

Bodrijar, Ž. (1991). Simulakrumi i simulacija [Simulacra and Simulation]. Novi Sad: IP Svetovi. 
Castells, M. (2000). Uspon umrě̌enog društva [The Information Age: Economy, Society and Culture: Volume 1: The Rise of the Network Society]. Zagreb: Golden marketing.

Clark, I. (1999). Globalization and International Relations Theory. Oxford: Oxford University Press.

Čaušević, F. (2004). Finansijska globalizacija i ekonomski suverenitet [Financial Globalization and Economic Sovereignty], Sociologija, Vol. 46(1) (2004), str. 71-95. doi:10.2298/SOC0401071C.

Диги, Л. (1929). Преображаји јавног права [Transformations of Public Law]. Београд: Издавачка књижарница Геце Кона.

Ганић, С. (2012). Државни суверенитет у светлу савременог међународног права [A State Sovereignty in the Light of Contemporary International Law]. Докторски рад. Београд: Правни факултет Универзитета у Београду.

Grubić, N. (2014). Koncepcije suverenosti: Od kraja 17. do sredine 20. stoljeća [Conceptions of Sovereignty: From late $17^{\text {th }}$ to mid-20 $0^{\text {th }}$ century]. Zbornik radova Veleučilišta u Šibeniku, No. 3-4, 2014, str. 7-34.

Hobs, T. (2004). Levijatan: ili građa, oblik i moć crkvene i građanske države [Leviathan or The Matter, Forme and Power of a Common-Wealth Ecclesiasticall and Civil]. Zagreb: Jesenski i Turk.

Ibler, V. (1972). Rječnik međunarodnog javnog prava [Dictionary of International Public Law]. Zagreb: Informator.

Јелинек, Г. (1998). Борба старог с новим правом [Conflict of the Old and the New $L a w]$. Београд: Правни факултет Универзитета у Београду.

Јовановић, С. (1996). О суверености - уводно предавање из државног права [Авоит Sovereignty - Introductory Lecture from State Law]. Ниш: Градина.

Јовановић, С. (1922). О држави: основи једне правне теорије [About a State: the Basis of a Legal Theory]. Београд: Издавачка књижарница Геце Кона.

Kelleh, F. (2012). The Changing Paradigm of State Sovereignty in the International System. Kansas city: University of Missouri.

Kelzen, H. (2000). Cista teorija prava [Pure Theory of Law]. Beograd: Gutenbergova galaksija.

Kovačević, B. (2016). Država i desuverenizacija [State and Desovereignization]. Banja Luka: Evropski defendologija centar za naučna, politička, ekonomska, socijalna, bezbjedonosna, sociološka i kriminološka istraživanja, Banja Luka.

Kovačević, I. (2013). Globalizacija i ekonomska i politička desuverenizacija [Globalization and Economic and Political Desovereignization]. Y: Глобализаиија и десуверенизачија: међународни тематски зборник (433448). Косовска Митровица: Филозофски факултет у Универзитета у Приштини.

Krasner, S. (2001). Abiding Sovereignty. International Political Science Review, Vol.22, No.3, 229-251.

Krastev, I. (2002). The Inflexibility Trap, Frustrated Societies, Weak States and Democracy. Sofia: Centre for Liberal Strategies: Institute for Market Economics.

Krbek, I. (1964). Suverenitet [Sovereignty]. Zagreb: Rad JAZU, knjiga 334.

Krbek, I. (1965). Suverenitet [Sovereignty]. Zagreb: Rad JAZU, knjiga 339.

Кузмановић, Р. (1999). Уставно Право [Constitutional Law]. Бања Лука: Универзитетска књига.

Ле Фир, Л. (1934). Међународно јавно право [Public International Law]. Београд: Издавачка књижарница Геце Кона.

Лукић, Р. (2014). Хегелова филозофија државе и права [Hegel's Philosophy of State and Law]. У: Филозофскоправни чланци (5-34). Београд: Досије студио. 
Марковић, Ч. (1927). Дигиева правна теорија [Theory of Law by Digi]. Суботица: Градска штампарија.

Марковић, Р. (1995). Уставно право и политичке институиије [Constitutional Law and Public Institutions]. Београд: Службени гласник.

Миловановић, М. (1997). Државно право и друге уставноправне студије [State Law and Other Constitutional Studies]. Београд: Службени гласник.

Mratović, V., Filipović, N., Sokol, S. (1986). Ustavno pravo i političke institucije: (SFRJ i komparativno): II izdanje [Constitutional Law and Political Institutions: (Yugoslavia and comparative study): $2^{\text {nd }}$ edition]. Zagreb/Beograd: Pravni fakultet, Centar za stručno usavršavanje i suradnju s udruženim radom, Poslovna politika.

Nešković, R. (2014). Osnovne protivrječnosti sadržaja i oblika suverenosti u kontekstu države i nacije [Basic Contradictions of the Content and Form of Sovereignty in the Context of State and Nation]. U: Globalizacija i suverenost - sa osvrtom na Bosnu i Hercegovinu: zbornik radova (67-75). Banja Luka: Evropski defendologija centar.

Новаковић, М. (1936). Основи међународнога јавнога права, књ. 1 [Fundamentals of International Public Law, Book 1]. Београд: Штампарија „Привредник”.

Orlović, S. (2010). Država u procesu globalizacije [The State in the Process of Globalization]. U: Slaviša Orlović: Politikološki ogledi (politička sociologija i politička teorija) (263-283). Beograd: Službeni glasnik.

Piketi, T. (2014). Kapital u XXI veku [Capital in the Twenty-First Century]. Novi Sad: Akademska knjiga.

Rakić, M. (2014). Desuverenizacija nacionalne države, ekonomije i bezbednosti u uslovima globalizacije [Desovereignization of National State, Economy and Security in Terms of Globalization]. Megatrend revija - Megatrend Review, Vol. 11, No 4, 2014, str. 405-416. doi:10.5937/MegRev1404405R.

Ristić, L. (2014). Globalizam i desuverenizacija [Globalization and seizing sovereignity]. U: Globalizacija i suverenost - sa osvrtom na Bosnu i Hercegovinu: zbornik radova (11-19). Banja Luka: Evropski defendologija centar.

Rousseau, J. (1993). Politički spisi [Oeuvres Completes Volume 3]. Zagreb: Informator: Fakultet političkih znanosti.

Samuelson, P. (1969). Ekonomija: uvodna analiza [Economics: An Introduction Analysis]. Beograd: Savremena administracija.

Савић, М. (2014). Право на сувереност држава и политичка реалност [The Right to Sovereignty and Political Realities]. U: Globalizacija i suverenost - sa osvrtom na Bosnu i Hercegovinu: zbornik radova (347-363). Banja Luka: Evropski defendologija centar.

Симић, М., Ђорђевић, С., Матић, Д. (2009). Увод у право [An Introduction to Law]. Крагујевац: Правни факултет, Институт за правне и друштвене науке.

Tadić, Lj. (1996). Filozofija prava [Philosophy of Law]. Beograd: Zavod za udžbenike i nastavna sredstva.

Трајковић, М. ( 2009). Теоријскоправни приступ одређењу права [Theoretical and Legal Approach to the Definition of Law]. Зборник радова Правног факултета у Нишу, бр. 54, 2009, стр. 109-126.

Видојевић, 3. (2013). Глобализација, десуверенизација и ресуверенизација [Globalization, Desovereignization and Resovereignization]. У: Глобализаиија и десуверенизација: међународни тематски зборник (191-213). Косовска Митровица: Филозофски факултет Универзитета у Приштини.

Вулетић, В. (2013). Глобализација и десуверенизација [Globalization and Sovereignty Decline]. У: Глобализација и десуверенизачија: међународни тематски зборник 2 (251-265). Косовска Митровица: Филозофски факултет у Универзитета у Приштини. 


\title{
UNDERSTANDING OF SOVEREIGNTY AND GLOBALIZATION WITH EMPHASIS ON SERBIAN TRANSITIONAL DISCOURSE
}

\author{
Vojislav Bačanin \\ University of Kragujevac, Faculty of Law, Kragujevac, Serbia
}

\begin{abstract}
Summary
We are witnesses that the process of globalization has led to a weakening of the political and economic power of states in relation to regional, international and transnational entities. The logic of capital, which is always aimed at avoiding political and legal regulation and logic of politics, which is always aimed at controlling the former - have constituted the basis of international relations for centuries. It is not uncommon for the state to sacrifice its economic prosperity in order to preserve political independence as its ultimate value. Furthermore, each relationship must have its own aspect of power. However, exploring this aspect is the subject of research within politics. The legal framework is only there to provide a platform that will ensure that, with constant fluctuations, a balance of power is enabled in the end.

Acknowledging the efforts of all those authors within the wide field of social sciences who have opted for the distinction of the so-called internal and external sovereignty, decomposition of the notion of sovereignty, accepting or negating it in the form of the so-called desovereignization, appears not to have changed the notion of sovereignty in the formal legal sense. We could speak about the erosion of sovereignty, desovereignization or similar viewpoints, only as an issue of understanding the political balance of power. The role of states has indeed been transformed at the political and economic level since the end of the WWII, but sovereignty, as a necessary segment of one of the elementary norms of international public law, still remains prevalent. States remain the dominant entities in international relations. They manage and control international organizations, have huge military power and a crucial influence on the functioning of military alliances, and, equally significant, they perform very important socio-economic functions. It seems that, even at this moment in this field, one cannot find any other entity that would present a fierce rival to the states. The political functionality of the states depends and will continue to depend largely on the cooperative ability of their actions. If the focus of the world public sphere continues to be on issues such as migrant crises, environmental problems and armed conflicts - the power of international organizations will increase. And without states - they cannot exist.

Finally, economic interdependence remains within the lines of the basis of international relations. The fact that the influence of the IMF, the World Bank or the WTO on the macroeconomic stability level of most countries remains dominant cannot be overlooked. However, it seems that this influence is not so much linked to the erosion of sovereignty or some desovereignization of states as subjects of international law, as far as it is related to the erosion of the state of well-being, as a wider social construct. Thus, in order to avoid dilemmas in the comprehension of the complex concept of sovereignty, it would be advisable that in the future scientific-research projects, which are certain to be undertaken, the authors primarily opt for a certain methodological approach, and after that decide on the specific concept of sovereignty as well as its legal, economic or political contextualization, and only then provide some kind of evaluation.
\end{abstract}

